\title{
Divergent effect of fluoxetine on the response to physical or chemical stressors in zebrafish
}

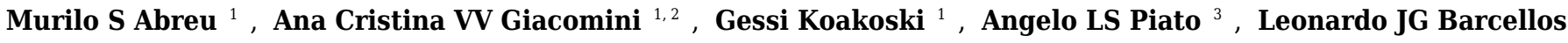 \\ Corresp. 1,4 \\ 1 Programa de Pós-Graduação em Farmacologia, Universidade Federal de Santa Maria (UFSM), Santa Maria, RS, Brazil \\ 2 Universidade de Passo Fundo (UPF), Passo Fundo, RS, Brazil \\ 3 Programa de Pós-Graduação em Farmacologia e Terapêutica, Universidade Federal do Rio Grande do Sul (UFRGS), Porto Alegre, RS, Brazil \\ 4 Programa de Pós-Graduação em Bioexperimentação, Universidade de Passo Fundo (UPF), Passo Fundo, RS, Brazil \\ Corresponding Author: Leonardo JG Barcellos \\ Email address: Ibarcellos@upf.br
}

Fluoxetine is a selective serotonin reuptake inhibitor (SSRI) that increases serotonin concentration in the central nervous system and modulates various systems, including the control of sympathetic outflow and the hypothalamus-pituitary-adrenal. However, it is not yet established whether fluoxetine can modulate the responses to stressors stimulants (physical or chemical) that trigger cortisol response in zebrafish. We demonstrate that fluoxetine blunts the response to physical stress, but not to chemical stress. 


\section{Divergent effect of fluoxetine on the response to physical or chemical}

2 stressors in zebrafish

3

4 Murilo S. Abreu ${ }^{1}$, Ana Cristina V. V. Giacomini ${ }^{1,2}$, Gessi Koakoski ${ }^{1}$, Angelo L. Piato ${ }^{3}$, Leonardo 5

$$
\text { J. G. Barcellos }{ }^{1,4} \text { * }
$$

6 1 Programa de Pós-Graduação em Farmacologia, Universidade Federal de Santa Maria (UFSM),

7 Santa Maria, RS, Brazil.

$8 \quad{ }^{2}$ Universidade de Passo Fundo (UPF), Passo Fundo, RS, Brazil

$9{ }^{3}$ Programa de Pós-Graduação em Farmacologia e Terapêutica, Universidade Federal do Rio

10 Grande do Sul (UFRGS), Porto Alegre, RS, Brazil.

$11{ }^{4}$ Programa de Pós-Graduação em Bioexperimentação, Universidade de Passo Fundo (UPF),

12 Passo Fundo, RS, Brazil.

13

14

15

16

17

18

19

20

21

22

23
* Correspondence to:

Leonardo José Gil Barcellos

e-mail address: 1barcellos@upf.br

Tel: +55543316.8100

Fax: +55 543316.8487 


\section{Abstract}

25 Fluoxetine is a selective serotonin reuptake inhibitor (SSRI) that increases serotonin 26 concentration in the central nervous system and modulates various systems, including the control 27 of sympathetic outflow and the hypothalamus-pituitary-adrenal. However, it is not yet 28 established whether fluoxetine can modulate the responses to stressor stimuli (physical or 29 chemical) that trigger cortisol response in zebrafish. We demonstrate that fluoxetine blunts the 30 response to physical stress, but not to chemical stress.

31

32

33

34

35

36

37

38

39

40 


\section{Introduction}

Fluoxetine (FLU), a selective serotonin reuptake inhibitor (SSRI), increases serotonin concentration in the central nervous system (Wong et al., 1995). Serotonin is one of the major neurotransmitters in the central nervous system and modulates various systems, including the control of sympathetic outflow and the hypothalamus-pituitary-adrenal axis (HPA), via serotonergic fibers that innervate structures such as the hippocampus, prefrontal cortex, amygdala and hypothalamus (Lowry, 2002). SSRIs and cognitive-behavioral therapy are both effective treatments for generalized anxiety disorder, and are know to reduce the peak of cortisol in older adults (Rosnick et al., 2016). Fluoxetine has been shown to blunt the cortisol response (Abreu et al., 2014) and, as a consequence, prevent stress-related osmoregulation changes in zebrafish (Abreu et al., 2015). In addition, fluoxetine reverses the anxiogenic effects of acute (Giacomini et al., 2016) and chronic (Marcon et al., 2016) stress in this species.

Stress depends on a stressor stimulus to occur, and in mammals it triggers a stimulatory process in the hippocampus and amygdala (LeDoux, 2000; 2007). In the hypothalamus, stress stimulates the release of corticotropin-releasing factor (CRF), which is the key neurotransmitter regulating the release of adrenocorticotropic hormone (ACTH) from the pituitary, which in turn induces the release of glucocorticoids (cortisol) from the adrenal. In teleost fish like in zebrafish, the hypothalamic-pituitary-interrenal axis (HPI axis) is the HPA axis homolog (Wendelaar Bonga, 1997).

Stress stimuli can be varied (e.g., social, physical, chemical), such as exposures to neighborhood-level violence, which can influence physiological and cellular markers of stress, even in children (Theall et al., 2017). In addition, physical stimuli elicit robust stress responses in fish (Perry et al., 1996). Physical stressors such as chasing have been used as standardized 
64 stressors (Abreu et al., 2014; Giacomini et al., 2015, 2016), and spatial restriction is used as a 65 stress model for behavioral assessment in zebrafish (Piato et al., 2011; Ghisleni et al., 2012).

66 Stressor stimulus can also be chemical, such as alarm substances, originally described in the 67 minnow (Phoxinus phoxinus) (Frisch, K 1941), which are produced and stored in epidermal 68 'club' cells (Barbosa Jr et al., 2012) and are released into the water after skin injuries as those 69 provoked by predator attack (Chivers \& Smith, 1998; Korpi \& Wisenden, 2001). Alarm 70 substance is known to induce fear responses in a range of fish species (Pfeiffer W, 1977). 71 Moreover, blood (Barreto et al., 2013) and diamines (putrescine and cadaverine) (Hussain et al., 72 2013) have also been documented as potential chemical stressors. However, it is not yet

established whether FLU can modulate the responses to different modalities of stressor stimuli (physical or chemical) that trigger cortisol response in zebrafish.

\section{Materials and Methods}

\subsection{Experimental animals}

A stock population of 200 mixed-sex (50/50) 180-day-old wild-type zebrafish (D. rerio), weighing $0.45 \pm 0.05 \mathrm{~g}$, short-fin (SF) strain, was maintained in two tanks equipped with biological filters, under constant aeration, and with a natural photoperiod (approximately $14 \mathrm{~h}$ light: $10 \mathrm{~h}$ dark). Water temperature was maintained at $26 \pm 1{ }^{\circ} \mathrm{C}$; $\mathrm{pH}$ at $7.0 \pm 0.2$; dissolved oxygen at $6.1 \pm 0.2 \mathrm{mg} / \mathrm{L}$; total ammonia at $<0.01 \mathrm{mg} / \mathrm{L}$; total hardness at $6 \mathrm{mg} / \mathrm{L}$; and alkalinity at $22 \mathrm{mg} / \mathrm{L} \mathrm{CaCO}_{3}$. This study was approved by the Ethics Commission for Animal Use (CEUA) of Universidade de Passo Fundo, UPF, Passo Fundo, RS, Brazil (Protocol \#29/2014-CEUA) and met the guidelines of Conselho Nacional de Controle de Experimentação Animal (CONCEA). 


\section{7}

88

89

90

91

92

93

94

95

96

97

98

99

100

101

102

103

104

105

106

108

107 2.2.2. Chemical stimuli on stress response 109 of 10 animals (duplicate) that were submitted or not to the following types of chemical stress:

\subsection{Experimental protocol}

Our aim was to verify whether FLU modulates cortisol changes induced by physical and chemical stressors in zebrafish. After a 15-day period for acclimation to laboratory conditions, fish were randomly distributed into two groups, i.e., untreated fish (control group) and fish exposed to FLU. The latter group was exposed to FLU (Daforin $\AA$, EMS, Brazil) at a concentration of $50 \mu \mathrm{g} / \mathrm{L}$ for $15 \mathrm{~min}$. before the stressor stimuli (Figure 1); this concentration and duration of exposure were previously shown to elicit behavioral responses (Giacomini et al., 2016) and decrease cortisol response in acute chasing stress (Abreu et al., 2014).

\subsubsection{Physical stimuli on stress response}

To evaluate the physical stress response, we then subdivided control and treated fish into groups of 10 animals (duplicate) that were submitted or not to the following types of physical stress: chasing with a net (duration 2 min., and waiting to complete 15 min to sampling); spatial restriction in a microtube (duration $15 \mathrm{~min}$ ) (Fig. 1A). After the $15 \mathrm{~min}$ of exposure to each stressor, fish were captured, euthanized by decapitation with medulla sectioning and immediately frozen in liquid nitrogen for storage at $-80{ }^{\circ} \mathrm{C}$ until cortisol extraction (Figure 1). This time interval was based on previous studies showing that cortisol levels peak 15 min following presentation of a stressor stimulus (Abreu et al., 2014; Idalencio et al., 2014; Ramsay et al., 2009).

08 To evaluate the chemical stress response, we then subdivided control and treated fish into groups 
110 exposure to conspecific blood (duration $15 \mathrm{~min}$ ); and exposure to alarm substance of 111 conspecifics (duration $15 \mathrm{~min}$ ). Exposure to blood (5 mL, extracted from zebrafish and jundia

112 (Rhamdia quelen) - the use of jundia blood was due to the low yield of zebrafish blood

113 extraction) was in a 10-L aquarium (Barreto et al., 2013); and exposure to alarm substance of 114 conspecifics (Speedie \& Gerlai, 2008) (1 mL, zebrafish) was in a 10-L aquarium (Barreto et al., 115 2010). After 15 min of exposure to each stressor, fish were captured, euthanized and stored as 116 described above (Fig. 1B). For collection of fish blood (zebrafish and jundia), fish were 117 anesthetized by eugenol (400 mg/L), the anesthesia occurred in less than 1 minute and 118 determined by total loss of opercular movement followed by cardiac arrest; then the caudal 119 peduncle was sectioned for the collection of blood. For extraction of alarm substance, fish were 120 quickly killed by medulla sectioning, then shallow cuts were made on each side of fish and the 121 cuts were washed with distilled water; at the end of the process a total of $100 \mathrm{~mL}$ of alarm 122 substance in solution were collected (Speedie \& Gerlai, 2008).

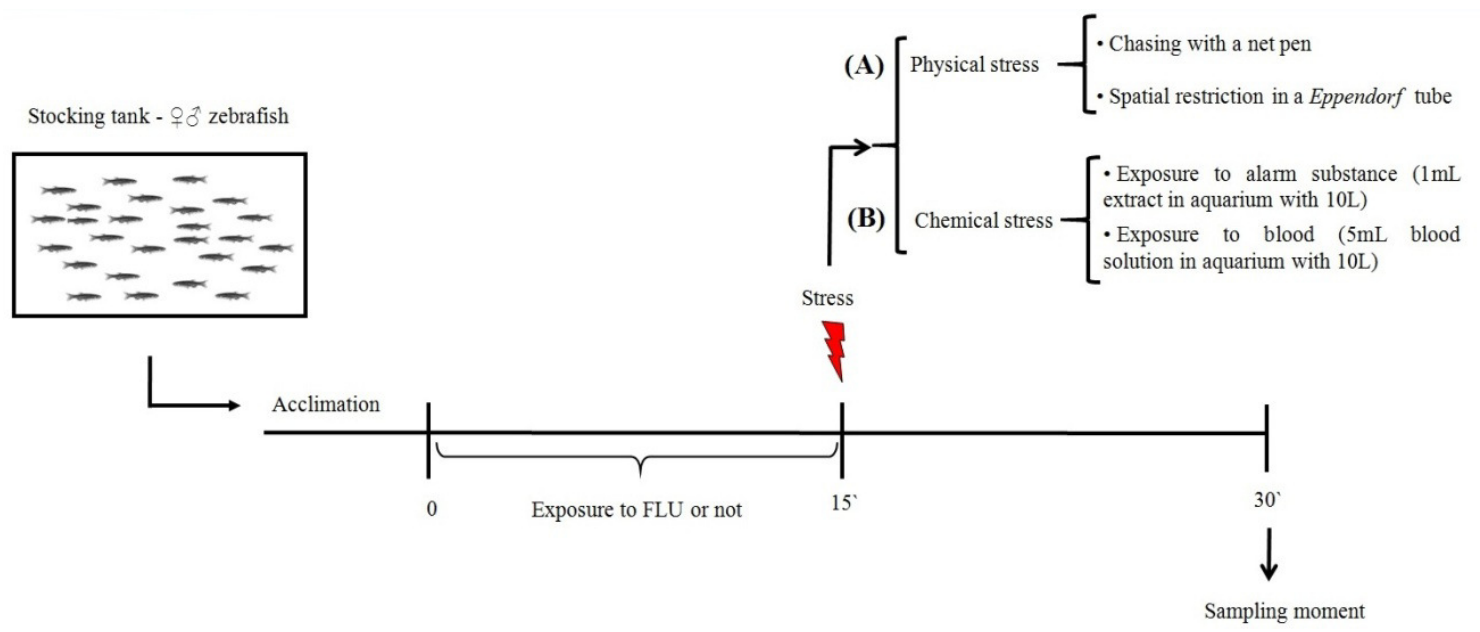

Figure 1. Schematic representation of the experimental design. 
127

128

129

130

131

132

133

134

135

136

137

138

139

140

141

142

143

144

145

146

147

148

149

150

\subsection{Cortisol analysis}

Whole-body cortisol levels were determined using the method described by Sink et al., 2007.

Fish were weighed, minced and homogenized with phosphate buffered saline (PBS, pH 7.3).

Samples were transferred into tubes with ether, vortexed, centrifuged, and then immediately frozen in liquid nitrogen (three times this last process). The unfrozen portion (ethyl ether containing cortisol) was decanted and transferred to a new tube and completely evaporated, yielding a lipid extract containing the cortisol. The samples were then placed on the plate of enzyme-linked immunosorbent assay kit. The accuracy was tested by calculating the recoveries from samples spiked with known amounts of cortisol (50, 25 and $12.5 \mathrm{ng} / \mathrm{mL})$, the mean detection of spiked samples was $94.3 \%$. All cortisol values were adjusted for recovery with the following equation: cortisol value $=$ measured value $\times 1.0604$. Whole-body cortisol levels were measured in duplicate for each extraction using the commercially available enzyme-linked immunosorbent assay kit (EIAgen CORTISOL test, BioChem Immunosystems). Reading was carried out in microplate reader equipment (ASYS UVM 340, ASYS, England).

\subsection{Statistical analysis}

After testing the homogeneity of variance and normality of data (Hartley and Kolmogorov-Smirnov tests, respectively), we compared the whole-body cortisol levels using two-way analysis of variance (ANOVA) followed by Dunnett's post hoc test. Differences were considered statistically significant at $\mathrm{p}<0.05$. The data are expressed as mean + standard error of mean (SEM).

\section{Results}

\subsection{Physical stimuli on stress response}



cortisol levels, and FLU blunted the increase in cortisol levels in fish subjected to physical

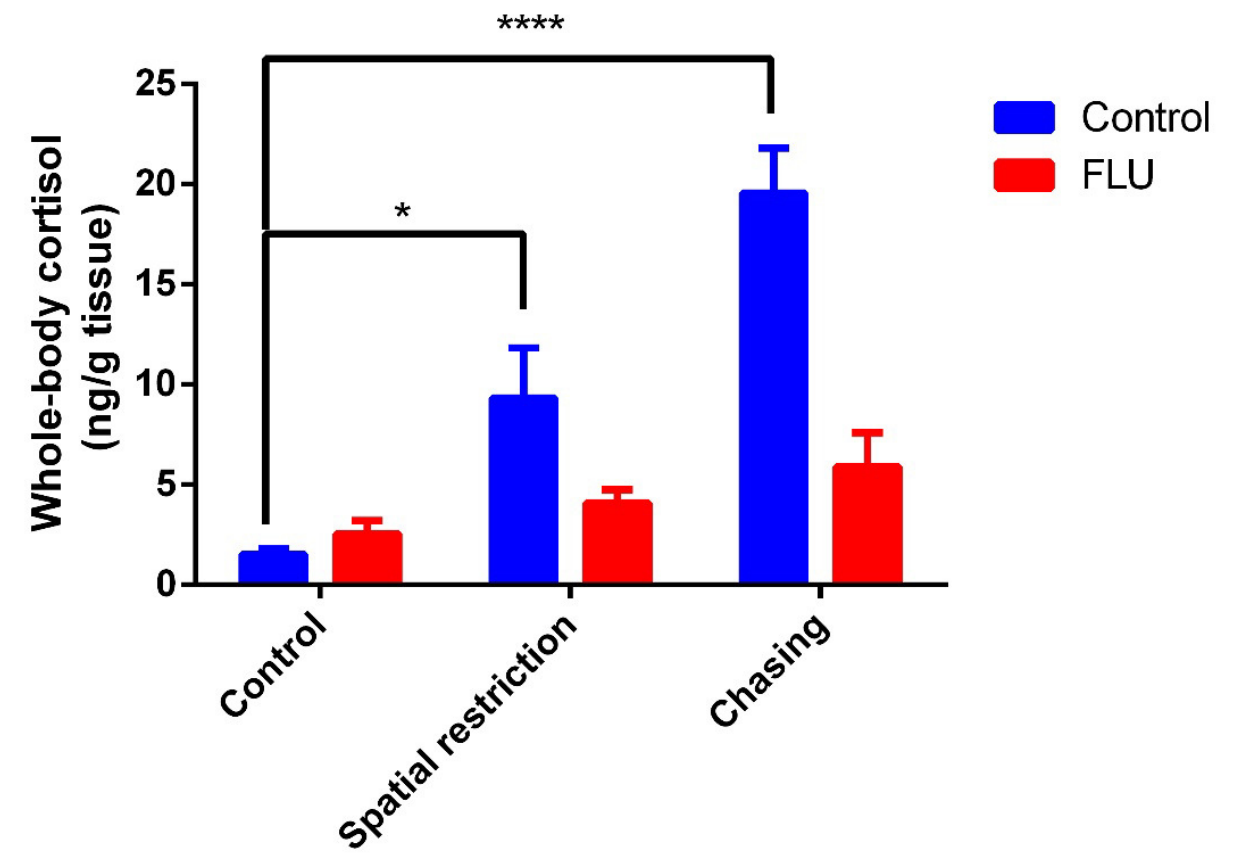

Figure 2. Effects of physical acute stressors (spatial restriction or chasing) on cortisol levels in whole-body zebrafish. Data were expressed as mean + SEM. Two-way ANOVA followed by Dunnett's post hoc test. FLU (fluoxetine). ${ }^{*} \mathrm{p}<0.05$ and $* * * * \mathrm{p}<0.0001$.

\subsection{Chemical stimuli on stress response}

Fish exposed to chemical stressors (alarm substance or blood) displayed an increase in 
165 stressors (Figure 3). Two-way ANOVA revealed a significant main effect of stress $\left(\mathrm{F}_{2,48}=\right.$

$1665.623, p=0.0064)$, but not interaction effect between the factors $\left(F_{2,48}=0.7045, p=0.4994\right)$ or a 167 main effect of drug $\left(\mathrm{F}_{1,48}=0.01718, \mathrm{p}=0.8963\right)$.

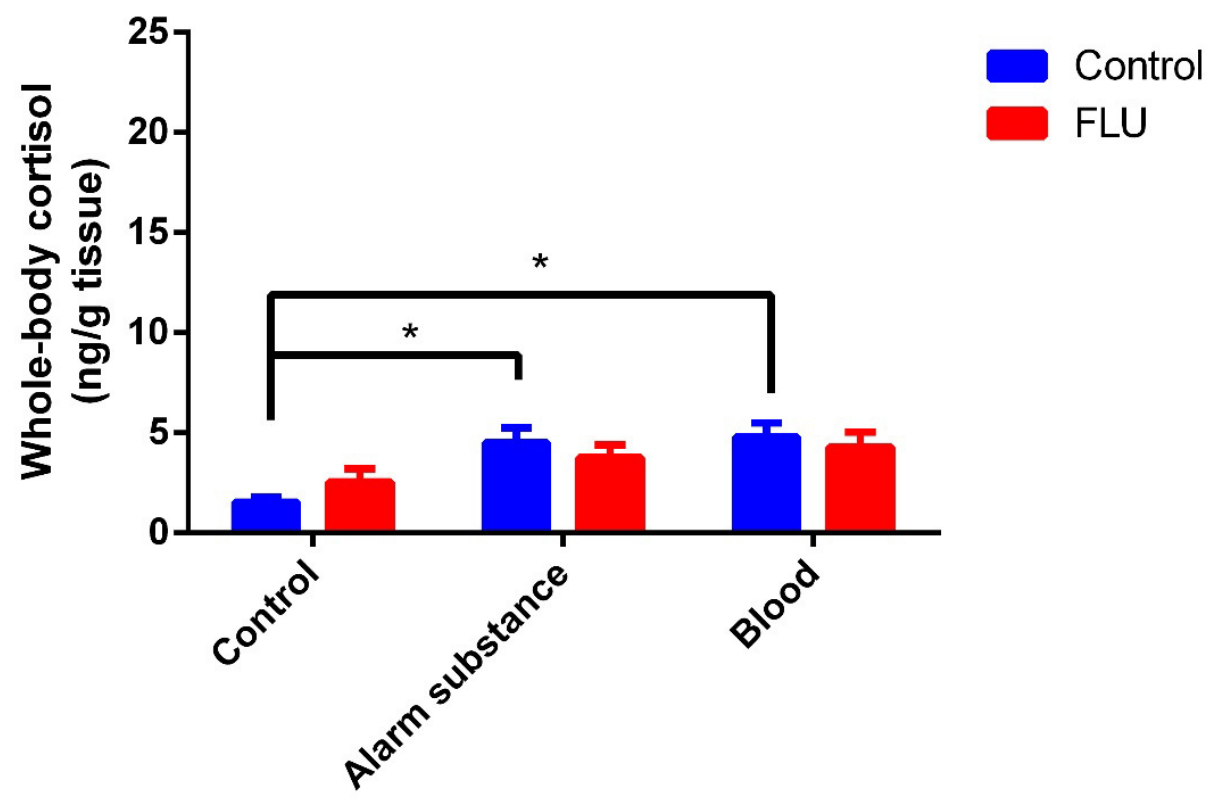

169

170

171

172

173

174

175

176

177 178

74

Figure 3. Effects of chemical acute stressors (alarm substance or blood) on cortisol levels in whole-body zebrafish. Data were expressed as mean + SEM. Two-way ANOVA followed by Dunnett's post hoc test. FLU (fluoxetine). $* \mathrm{p}<0.05$.

\section{Discussion}

Here we show that fluoxetine blunts the response to physical, but not chemical, stress.

Even if physical (Ramsay et al., 2009) or chemical (Teles et al., 2017) stress increase cortisol levels in zebrafish.

The greater magnitude of response to a physical stressor could be related to its high impact can cause a clear aversive response in fish (Abreu et al., 2016). Besides, confinement 
181 stress also resulted in elevated cortisol for being ' high-impact stress" (Silva et al., 2015),

182 perhaps physical stressors act in dorsolateral and dorsomedial regions of the pallium that have

183 been characterized as functional homologues to the mammalian amygdala and hippocampus

184 (Goodson \& Kingsbury, 2013; O'Connell \& Hofmann, 2011; Vargas et al., 2009), with

185 consequent action under the hypothalamus. On the other hand, chemical stress does not trigger a

186 response of such magnitude (Silva et al., 2015). Our hypothesis is that the chemical stressor

187 stimulus depends on more than one sensory pathway (e.g., smell, tactile) for the perception of the

188 stimulus, which would result in a suppression of the stimulation force of the hypothalamic 189 system, with consequent pituitary and later adrenergic stimulation.

We demonstrated that fluoxetine prevents the increase of cortisol in fish in response to

physical stressor stimulus. Previously, we showed that fluoxetine blocked cortisol response to

acute chasing stress in a dose-dependent manner (Abreu et al., 2014) as well as in fish subjected

to different forms of housing (Giacomini et al., 2016). Fluoxetine also blocked the stress

response following chronic exposure in zebrafish (Egan et al., 2009), besides stress increases serotoninergic activity in the telencephalon in fish (e.g. Øverli et al., 2004; Winberg et al., 1992).

In fact, the levels of serotonin in the brain regions considered homologous to the mammalian hippocampus and amygdala are altered in fish subjected to spatial restriction (Silva et al., 2015). This effect reinforces the participation of these regions in response to physical stress, as well as the involvement of serotonin in these pathways.

Still, we have shown that fluoxetine did not block the increase of cortisol in fish in response to chemical stressor stimulus. Alarm substance induced stress responses in Nile tilapia (Oreochromis niloticus), increasing ventilation rate and cortisol level (Sanches et al., 2015) as well as increasing erratic movements in zebrafish (Speedie \& Gerlai 2008). The exposure to 
204 blood has also been shown to induce antipredator behavior in the fish species Nile

205 tilapia (Barreto et al., 2013). The exposure to alarm substance also increased anxiety-like

206 behavior in the light/dark test in zebrafish and decreased nocifensive behavior, however

207 pretreatment with fluoxetine blocked the anxiogenic effects of alarm substance on the light/dark

208 test and also increased extracellular brain 5-HT (Maximino et al., 2014), the same behavioral

209 relationship between alarm substance and serotoninergic system was not observed in the

210 relationship between neuroendocrine and serotoninergic system. Serotonin receptors $\left(5-\mathrm{HT}_{1 \mathrm{~A}}\right.$

211 and $5-\mathrm{HT}_{4}$ ) expressed in steroidogenic cells in the interrenal glands mediate the effects of

212 serotonin on cortisol response, and this direct mechanism may underlie the effects of fluoxetine

213 observed in physical stress response, namely the inhibition of cortisol release.

\section{References}

216 Abreu MS, Giacomini AC, Koakoski, G, Oliveira TA, Gusso D, Baldisserotto B, Barcellos LJ.

217 2015. Effects of waterborne fluoxetine on stress response and osmoregulation in zebrafish.

218 Environmental Toxicology and Pharmacology 40: 704-707. DOI 10.1016/j.etap.2015.09.001.

219 Abreu MS, Giacomini ACV, Gusso D, Koakoski G, Oliveira TA, Marqueze A, Barreto 220 RE, Barcellos LJ. 2016. Behavioral responses of zebrafish depend on the type of threatening 221 chemical cues. J Comp Physiol A Neuroethol Sens Neural Behav Physiol 202: 895-901. DOI 222 10.1007/s00359-016-1129-5

223 Abreu MS, Koakoski G, Ferreira D, Oliveira TA, Rosa JS, Gusso D, Giacomini AC, Piato 224 AL, Barcellos LJ. 2014. Diazepam and fluoxetine decrease the stress response in zebrafish. PLoS 225 ONE 9 (7): e103232. DOI 10.1371/journal.pone.0103232

226 Barbosa Jr A, Alves FL, Pereira AS, Ide LM, Hoffmann A. 2012. Behavioral characterization 227 of the alarm reaction and anxiolytic-like effect of acute treatment with fluoxetine in piauçu fish. 228 Physiology \& Behavior 105: 784-790. DOI 10.1016/j.physbeh.2011.10.007

229 Barreto RE, Barbosa A, Giassi ACC, Hoffmann A. 2010. The'club' cell and behavioural and 230 physiological responses to chemical alarm cues in the Nile tilapia. Mar Fresh Behav Physiol 43: 231 75-81. DOI 10.1080/10236241003654139. 
232 Barreto RE, Miyai CA, Sanches FHC, Giaquinto PC, Delicio HC, Volpato GL. 2013. Blood 233 cues induce antipredator behavior in Nile tilapia conspecifics. Plos One 8: 54642. DOI 234 10.1371/journal.pone.0054642.

235 Chivers DP, Smith JF. 1998. Chemical alarm signalling in aquatic predator- prey systems: a 236 review and prospectus. Ecoscience 5: 338-352.

237 Egan RJ, Bergner CL, Hart PC, Cachat JM, Canavello PR, Elegante MF, Elkhayat SI, Bartels 238 BK, Tien AK, Tien DH, Mohnot S, Beeson E, Glasgow E, Amri H, Zukowska Z, Kalueff AV. 239 2009. Understanding behavioral and physiological phenotypes of stress and anxiety in zebrafish. 240 Behav Brain Res 205: 38-44. DOI 10.1016/j.bbr.2009.06.022.

241 Frisch K. 1941. Uber einen schreckstoff der fischhaut und seine biologische Bedeutung. $Z$ vergl 242 Physiol 29: 46-145.

243 Ghisleni G, Capiotti KM, Da Silva RS, Oses JP, Piato AL, Soares V, Bogo MR, Bonan CD. 244 2012. The role of CRH in behavioral responses to acute restraint stress in zebrafish. Progress in 245 Neuro-Psychopharmacology \& Biological Psychiatry 36: 176-182. DOI 246 10.1016/j.pnpbp.2011.08.016.

247 Giacomini AC, de Abreu MS, Koakoski G, Idalêncio R, Kalichak F, Oliveira TA, da Rosa 248 JG, Gusso D, Piato AL, Barcellos LJ. 2015. My stress, our stress: Blunted cortisol response to 249 stress in isolated housed zebrafish. Physiology \& Behavior 139: 182-187. DOI 1 $250 \quad 0.1016 /$ j.physbeh.2014.11.035.

251 Giacomini ACVV, Abreu MS, Giacomini LV, Siebel AM, Zimerman FF, Rambo CL, Mocelin 252 R, Bonan CD, Piato AL, Barcellos LJ. 2016. Fluoxetine and diazepam acutely modulate stress 253 induced-behavior. Behavioural Brain Research 296: 301-310. DOI 10.1016/j.bbr.2015.09.027.

254 Goodson JL, Kingsbury MA. 2013. What's in a name? Considerations of homologies and 255 nomenclature for vertebrate social behavior networks. Horm Behav 64: 103-112. DOI : 256 10.1016/j.yhbeh.2013.05.006.

257 Herculano AM, Maximino C. 2014. Serotonergic modulation of zebrafish behavior: Towards a 258 paradox. Progress in Neuro-Psychopharmacology \& Biological Psychiatry 55: 50-66. DOI 259 10.1016/j.pnpbp.2014.03.008.

260 Howe K, Clark MD, Torroja CF, Torrance J, Berthelot C, Muffato M, Collins JE, Humphray 261 S, McLaren K, Matthews L, McLaren S, Sealy I, Caccamo M, Churcher C, Scott C, Barrett 262 JC, Koch R, Rauch GJ, White S, Chow W, Kilian B, Quintais LT, Guerra-Assunção JA, Zhou 263 Y, Gu Y, Yen J, Vogel JH, Eyre T, Redmond S, Banerjee R, Chi J, Fu B, Langley E, Maguire 264 SF, Laird GK, Lloyd D, Kenyon E, Donaldson S, Sehra H, Almeida-King J, Loveland 265 J, Trevanion S, Jones M, Quail M, Willey D, Hunt A, Burton J, Sims S, McLay K, Plumb 266 B, Davis J, Clee C, Oliver K, Clark R, Riddle C, Elliot D, Threadgold G, Harden G, Ware 
267 D, Begum S, Mortimore B, Kerry G, Heath P, Phillimore B, Tracey A, Corby N, Dunn 268 M, Johnson C, Wood J, Clark S, Pelan S, Griffiths G, Smith M, Glithero R, Howden P, Barker 269 N, Lloyd C, Stevens C, Harley J, Holt K, Panagiotidis G, Lovell J, Beasley H, Henderson 270 C, Gordon D, Auger K, Wright D, Collins J, Raisen C, Dyer L, Leung K, Robertson 271 L, Ambridge K, Leongamornlert D, McGuire S, Gilderthorp R, Griffiths C, Manthravadi 272 D, Nichol S, Barker G, Whitehead S, Kay M, Brown J, Murnane C, Gray E, Humphries 273 M, Sycamore N, Barker D, Saunders D, Wallis J, Babbage A, Hammond S, Mashreghi274 Mohammadi M, Barr L, Martin S, Wray P, Ellington A, Matthews N, Ellwood M, Woodmansey 275 R, Clark G, Cooper J, Tromans A, Grafham D, Skuce C, Pandian R, Andrews R, Harrison 276 E, Kimberley A, Garnett J, Fosker N, Hall R, Garner P, Kelly D, Bird C, Palmer S, Gehring 277 I, Berger A, Dooley CM, Ersan-Ürün Z, Eser C, Geiger H, Geisler M, Karotki L, Kirn 278 A, Konantz J, Konantz M, Oberländer M, Rudolph-Geiger S, Teucke M, Lanz C, Raddatz 279 G, Osoegawa K, Zhu B, Rapp A, Widaa S, Langford C, Yang F, Schuster SC, Carter NP, Harrow 280 J, Ning Z, Herrero J, Searle SM, Enright A, Geisler R, Plasterk RH, Lee C, Westerfield M, de 281 Jong PJ, Zon LI, Postlethwait JH, Nüsslein-Volhard C, Hubbard TJ, Roest Crollius H, Rogers 282 J, Stemple DL.. 2013. The zebrafish reference genome sequence and its relationship to the 283 human genome. Nature 496 (7446): 498-503. DOI 10.1038/nature 1211.

284 Hussain A, Saraiva LR, Ferrero DM, Ahuja G, Krishna VS, Liberles SD, Korsching SI. 2013. 285 High-affinity olfactory receptor for the death-associated odor cadaverine. Proc. Natl. Acad. Sci. 286 U. S. A. 110: 19579-19584. DOI 10.1073/pnas.1318596110.

Idalencio R, Kalichak F, Rosa JGS, Oliveira TA, Koakoski G, Gusso D, Abreu MS, Giacomini AC, Barcellos HH, Piato AL, Barcellos LJ. 2015. Waterborne Risperidone Decreases Stress Response in Zebrafish. Plos One 10: e0140800. DOI 10.1371/journal.pone.0140800.

290

291

292

293

294

295

296

297

298

299

300

301

Kalueff AV, Echevarria DJ, Stewart AM. 2014. Gaining translational momentum: more zebrafish models for neuroscience research. Progress in neuro-psychopharmacology \& biological psychiatry 55: 1-6. DOI 10.1016/j.pnpbp.2014.01.022.

Korpi NL, Wisenden BD. 2001. Learned recognition of novel predator odour by zebra danio, Danio rerio, following time-shifted presentation of alarm cue and predator odour. Environmental Biology of Fishes 61: 205-211.

LeDoux J. 2007. The amygdala. Curr. Biol. 17: 868-874. DOI 10.1016/j.cub.2007.08.005

LeDoux JE. 2000. Emotion circuits in the brain. Annu. Rev. Neurosci. 23: 155-184.

Lowry CA. 2002. Functional subsets of serotonergic neurones: implications for control of the hypothalamic-pituitary-adrenal axis. J Neuroendocrinol 14: 911-23.

Marcon M, Herrmann AP, Mocelin R, Rambo CL, Koakoski G, Abreu MS, Conterato GM, Kist LW, Bogo MR, Zanatta L, Barcellos LJ, Piato AL. 2016. Prevention of unpredictable chronic 
302 stress-related phenomena in zebrafish exposed to bromazepam, fluoxetine and nortriptyline. 303 Psychopharmacol. 233: 3815-3824.

304 Maximino C, Lima MG, Costa CC, Guedes IML, Herculano AM. 2014. Fluoxetine and WAY 305100.635 dissociate increases in scototaxis and analgesia induced by conspecific alarm substance 306 in zebrafish (Danio rerio Hamilton 1822). Pharmacol. Biochem. Behav. 124: 425-433. DOI 1 307 0.1016/j.pbb.2014.07.003.

308 O'Connell LA, Hofmann HA. 2011. The Vertebrate mesolimbic reward system and social 309 behavior network: A comparative synthesis. J Comp Neurol 519: 3599-3639. DOI $31010.1002 /$ cne.22735.

311 Øverli Ø, Korzan WJ, Larson ET, Winberg S, Lepage O, Pottinger TG, Renner KJ, Summers $312 \mathrm{CH}$. 2004. Behavioural and neuroendocrine correlates of displaced aggression in trout. Horm. 313 Behav. 45: 324-329. DOI 10.1016/j.yhbeh.2004.01.001

314 Perry S, Reid S, Salama A. 1996. The effects of repeated physical stress on the $\beta$-adrenergic 315 response of the rainbow trout red blood cell. Journal of experimental biology 199: 549 -562.

316 Pfeiffer W. 1977. The distribution of fright reaction and alarm substance cells in fishes. Copeia 317 4: 653-65.

318 Piato AL, Rosemberg DB, Capiotti KM, Siebel AM, Herrmann AP, Ghisleni G, Vianna MR, 319 Bogo MR, Lara DR, Bonan CD. 2011. Acute restraint stress in zebrafish: behavioral parameters 320 and purinergic signaling. Neurochem. Res. 36: 1876-86.

321 Ramsay JM, Feist GW, Varga ZM, Westerfield M, Kent ML, Schreck CB. 2009. Whole-body 322 cortisol response of zebrafish to acute net handling stress. Aquaculture 297: 157-162.

323 Rosnick CB, Wetherell JL, White KS, Andreescu C, Dixon D, Lenze EJ. 2016. Cognitive324 behavioral therapy augmentation of SSRI reduces cortisol levels in older adults with generalized 325 anxiety disorder: A randomized clinical trial. J Consult Clin Psychol. 84(4): 345-52. DOI $326 \quad 10.1037 / \mathrm{a} 0040113$.

327 Sanches FHC, Miyai CA, Pinho-Neto CF, Barreto RE. 2015. Stress responses to chemical alarm 328 cues in Nile tilapia. Physiology \& Behavior 149: 8-13. DOI 10.1016/j.physbeh.2015.05.010.

329 Silva PIM, Martins CI, Khan UW, Gjøen HM, Øverli Ø., Höglund E. 2015. Stress and fear 330 responses in the teleost pallium. Physiology \& Behavior 141: 17-22.DOI 331 10.1016/j.physbeh.2014.12.020.

332 Sink TD, Kumaran S, Lochmann RT. 2007. Development of a whole-body cortisol extraction 333 procedure for determination of stress in golden shiners, Notemigonus crysoleucas. Fish Physiol. 334 Biochem. 33: 189-193. DOI 10.1007/s10695-007-9130-0. 
335 Speedie N, Gerlai R. 2008. Alarm substance induced behavioral responses in zebrafish (Danio 336 rerio). Behav. Brain Res. 188: 168-177. DOI 10.1016/j.bbr.2007.10.031.

337 Teles M, Soares AM, Tort L, Guimarães L, Oliveira M. 2017. Linking cortisol response with 338 gene expression in fish exposed to gold nanoparticles. Sci Total Environ. 17: 30163-8. DOI 339 10.1016/j.scitotenv.2017.01.153.

340 Theall KP, Shirtcliff EA, Dismukes AR, Wallace M, Drury SS. 2017. Association Between 341 Neighborhood Violence and Biological Stress in Children. JAMA Pediatr. 171(1): 53-60. DOI $34210.1001 /$ jamapediatrics.2016.2321.

343 Vargas JP, López JC, Portavella M. 2009. What are the functions of fish brain pallium? Brain 344 Res Bull 79: 436-440. DOI 10.1016/j.brainresbull.2009.05.008.

345 Wendelaar Bonga SE. 1997. The stress response in fish. Am. Physiol. Soc. Rev. 77: 591-625.

346 Winberg S, Nilsson GE, Olsen KH. 1992. The effect of stress and starvation on brainserotonin 347 utilization in Arctic charr (Salvelinus alpinus). J. Exp. Biol. 165: 229-239.

348 Wong DT, Bymaster FP, Engleman EA. 1995. Prozac (Fluoxetine, Lilly 110140), the first 349 selective serotonin uptake inhibitor and an antidepressant drug: twenty years since its first 350 publication. Life Sci. 57: 411-441. 